\title{
Unusual preservation of an Ordovician (Floian) arthropod from Peary Land, North Greenland (Laurentia)
}

\author{
John S. Peel ${ }^{1}$ (D) Sebastian Willman ${ }^{1} \cdot$ Stig A. Schack Pedersen ${ }^{2}$
}

Received: 14 June 2019 / Accepted: 10 July 2019 / Published online: 31 July 2019

(c) The Author(s) 2019

\begin{abstract}
Preservation of a fragment of an arthropod from starved trough sediments of the Bøggild Fjord Formation (Ordovician, Floian) of Johannes V. Jensen Land in north Peary Land, North Greenland, recalls that of the lower Cambrian Sirius Passet Lagerstätte of extreme north-west Peary Land and may suggest a second locality for exceptional preservation in North Greenland. A prominent petaloid pattern on the tergopleurae reflects impression onto the internal mould of terrace lines from the cuticle exterior. The arthropod is associated with poorly preserved sponges and a depauperate assemblage of organicwalled microfossils. It is tentatively compared to Mollisonia, originally described from the Burgess Shale Lagerstätte (middle Cambrian, Miaolingian Series) of Canada.
\end{abstract}

Keywords Arthropod · Preservation · Ordovician · Floian · North Greenland · Laurentia

\section{Introduction}

The tremendous diversification of highly organised life at the beginning of the Phanerozoic is witnessed in the Cambrian by a number of localities yielding exceptionally preserved fossils, the Konservat-Lagerstätten of Seilacher (1970). Foremost amongst these is the classic Burgess Shale Lagerstätte from the middle Cambrian (Miaolingian Series) of British Columbia, Canada (Briggs et al. 1994), but its diversity is exceeded by the early Cambrian (Series 2) Qingjiang Lagerstätte (Fu et al. 2019) and the Chengjiang Lagerstätte (Hou et al. 2017) of South China, the latter just one of numerous Cambrian Lagerstätten analysed by Holmes et al. (2018). The Sirius Passet Lagerstätte of

Handling Editor: Mike Reich.

John S. Peel

john.peel@pal.uu.se

Sebastian Willman

sebastian.willman@geo.uu.se

Stig A. Schack Pedersen

sasp@geus.dk

1 Department of Earth Sciences (Palaeobiology), Uppsala University, Villavägen 16, 75236 Uppsala, Sweden

2 Geological Survey of Denmark and Greenland, Øster Voldgade 10, 1350 Copenhagen K, Denmark north-west Peary Land, North Greenland (Fig. 1a) is one of the oldest Cambrian Lagerstätten (Cambrian Series 2, Stage 3; $517 \mathrm{Ma}$ ), and currently the oldest major site with exceptional preservation in Laurentia (Conway Morris et al. 1987; Ineson and Peel 2011; Peel and Ineson 2011a, b; Peel and Willman 2018). The geographically restricted fossiliferous locality lies within an outer shelf transitional facies of the Buen Formation, but extensive outcrops of the same formation in southern Peary Land have yielded small carbonaceous fossils, indicating that many elements of the Sirius Passet biota were probably more widely distributed (Slater et al. 2017; Peel and Willman 2018).

In contrast to the Cambrian, only a few major KonservatLagerstätten are currently known from the Ordovician, although recent reports indicate several new sites (Young et al. 2007; Botting et al. 2011, 2015; Van Roy et al. 2010). The most diverse Ordovician Lagerstätten occur within the Late Ordovician (Hirnantian) Soom Shale of South Africa (Gabbott et al. 2017) and the Early Ordovician (Tremadocian) Fezouata Formation of Morocco, North Africa (Van Roy et al. 2015; Lefebvre et al. 2016; Martin et al. 2016).

The fragment of an arthropod (Fig. 2a, d) described herein from the northernmost margin of Laurentia in North Greenland is of interest in suggesting the possible occurrence of another site with exceptional preservation. The specimen is similar in terms of its preservation to some of the arthropods described from the Sirius Passet Lagerstätte 

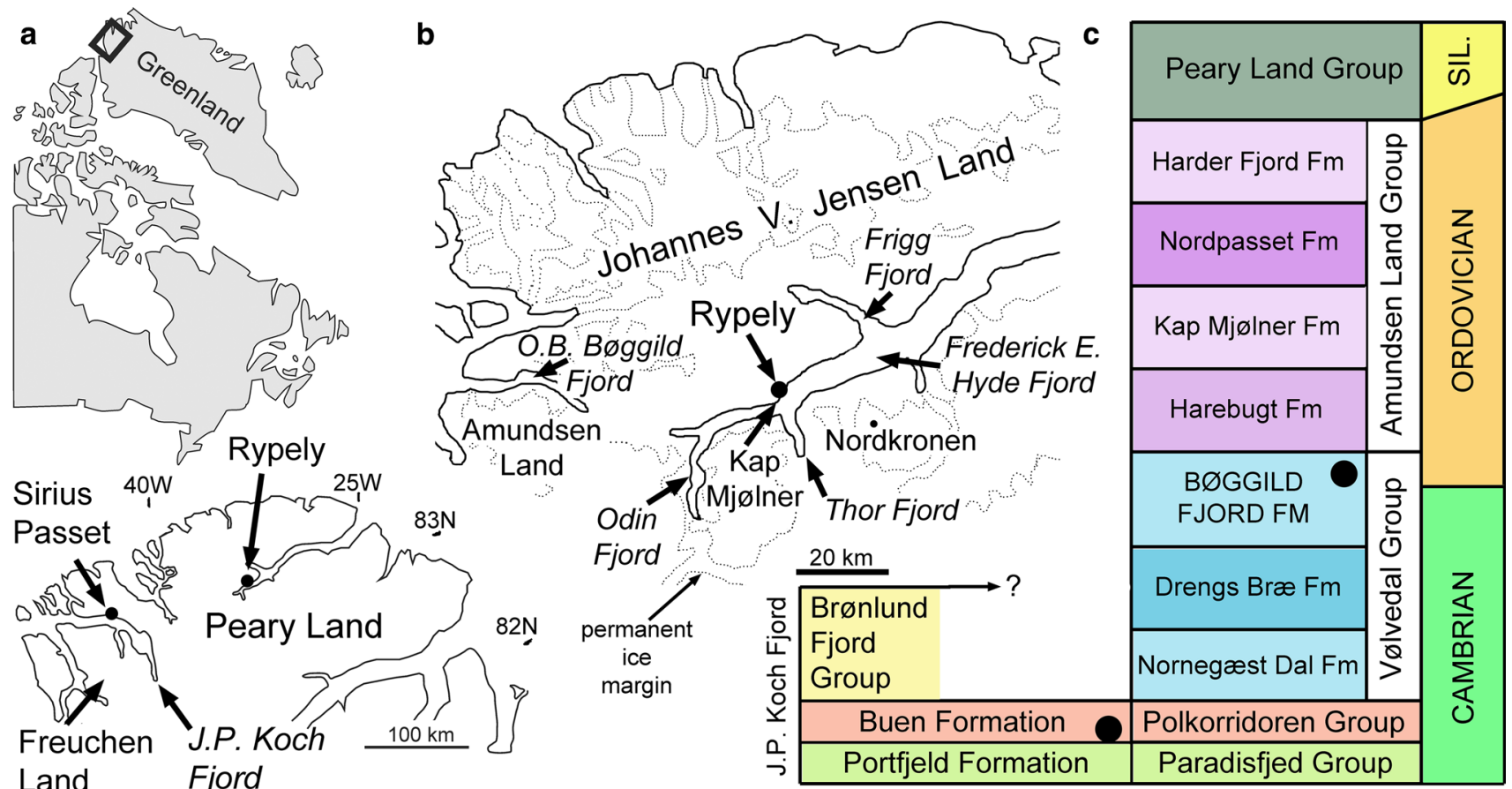

Fig. 1 Derivation of samples. a Overview showing location of the localities at Rypely and Sirius Passet; $\mathbf{b}$ geography of the area around Rypely; c stratigraphic nomenclature in southern Johannes V. Jensen

Land and Amundsen Land compared to the J.P. Koch Fjord area of western Peary Land. Localities at Rypely (Bøggild Fjord Formation) and Sirius Passet (Buen Formation) indicated by black dots

(Budd 1997, 1999a, b, 2011; Budd and Peel 1998; Stein 2010; Stein et al. 2010, 2013; Peel and Stein 2009; Peel 2017), but it is derived from the Early Ordovician (Floian), some 40 Ma younger than Sirius Passet. The unique specimen was collected from strata of the Bøggild Fjord Formation, the uppermost formation of a starved trough succession represented by the Vølvedal Group in southern Johannes V. Jensen Land (Higgins et al. 1991a, b; Fig. 1c). The locality lies some $130 \mathrm{~km}$ east of Sirius Passet, on the hillside above Rypely (Danish, meaning ptarmigan shelter, pronounced 'rewper-lew'; Fig. 1c). The location of Rypely is described by Grønnow and Jensen (2009: p. 291). Like Sirius Passet, Rypely is located within the largely uninhabited North Greenland National Park, entry to which is controlled by the Greenland civil authority. However, the locality is accessible by small aircraft with short-takeoff-and-landing capability in rough terrain.

Unfortunately, the lack of the head shield prevents accurate identification of the Rypely specimen, but the thorax allows speculative comparison to that of Mollisonia Walcott, 1912, a relatively rare arthropod originally described from the middle Cambrian (Miaolingian Series) Burgess Shale Lagerstätte of British Columbia (Walcott 1912).

Apart from its narrowly tapering thorax, the most striking feature of the Rypely specimen is a series of laterally disposed petaloid structures, one pair on each tergopleura within the thorax (Fig. 2a, b, d-f). Similar structures have

not been observed in fossils from Sirius Passet, and their function is equivocal. However, comparisons are made with a specimen of Mollisonia symmetrica Walcott, 1912 from the Burgess Shale.

\section{Geological background}

Lower Palaeozoic strata in North Greenland form part of the transarctic Franklinian Basin (Trettin 1989, 1991), with a deep water trough succession lying to the north of a southern carbonate-dominated shelf succession (Higgins et al. 1991a, b; Ineson and Peel 1997, 2011; Smith and Rasmussen 2008).

The Vølvedal Group was proposed by Friderichsen et al. (1982) for a starved trough sequence which crops out in southern Johannes V. Jensen Land. The group attains a thickness of 600-700 m. Three formations were briefly described by Higgins et al. (1991a, b), and their distribution was shown on 1:100,000 geological maps (Higgins 1986; Pedersen and Henriksen 1986). It should be noted that due to an unfortunate drafting error, these formations are listed in inverse order by Higgins et al. (1991a: fig. 2, 1991b: fig. 7.2), although correctly described in the accompanying text. The error was unwittingly perpetuated by Stijl and Mosher (1998: fig. 13).

Black non-bioturbated mudstones with thin turbidites of the Nornegæst Dal Formation are overlain by about $50 \mathrm{~m}$ 

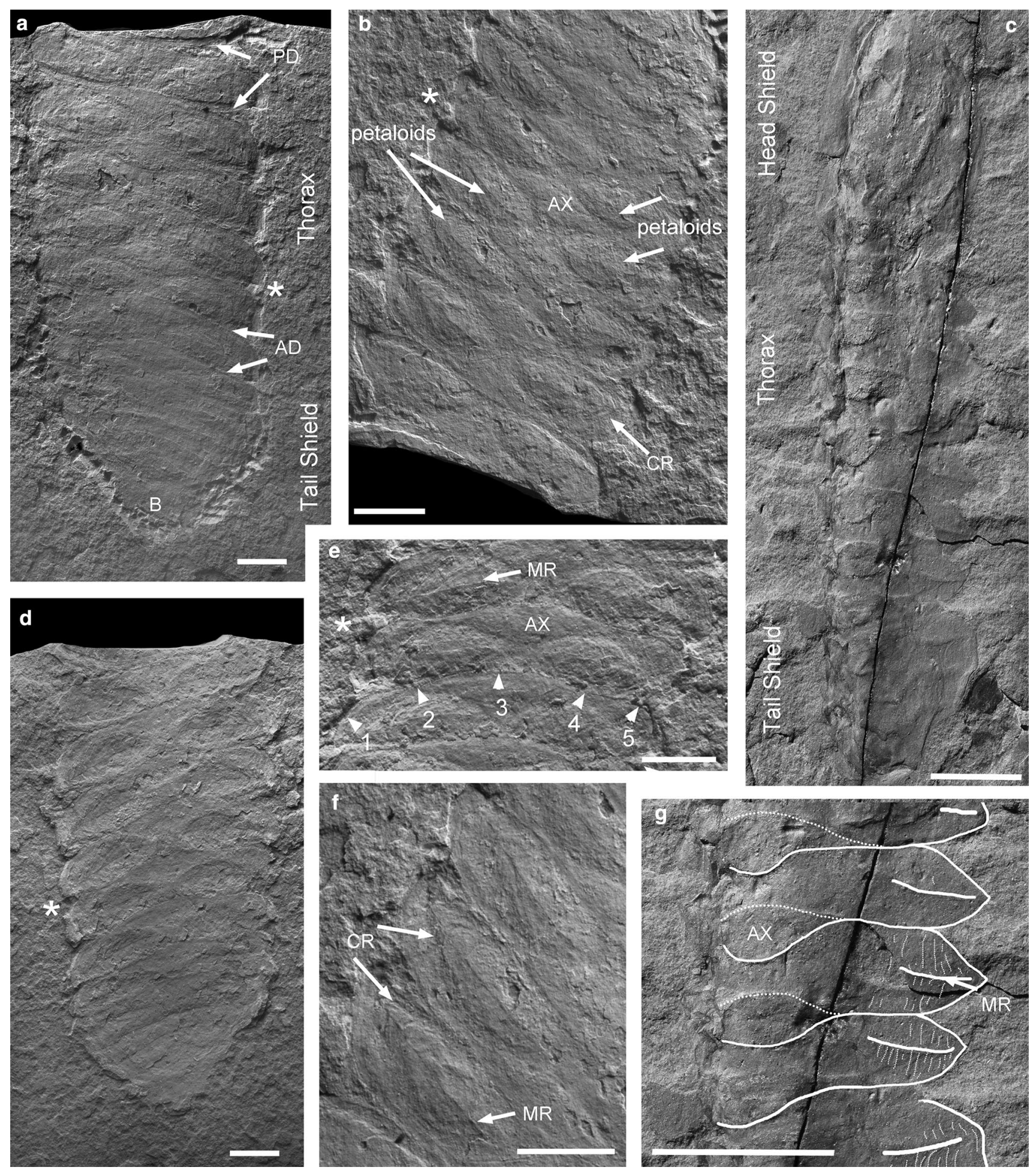

Fig. 2 a, b, d, e Mollisonia? sp. from Rypely. MGUH 33388 from GGU sample 217703, Bøggild Fjord Formation, southern Johannes V. Jensen Land, Ordovician (Floian); a dorsal view of part showing impressed anterior (AD) and posterior (PD) margins of tergopleurae; $\mathbf{b}$ oblique antero-dorsal view of part showing axial area $(\mathrm{AX})$ of tergopleura, petaloids and chevron ridges $(\mathrm{CR}) ; \mathbf{d}$ counterpart of $\mathbf{a}$, see Fig. 5a for interpretation; e detail of counterpart (d), with lighting from posterior showing median ridge of petaloid (MR) and the anterior margin of tergopleura (arrows 1-5), with the axial area (AX), overlapping the previous tergopleura on the interior of the tagma; $f$ petaloids (detail of $\mathbf{b}$ ) with median ridge (MR) and chevron ridges (CR). Asterisks locate equivalent points in $\mathbf{a}, \mathbf{b}, \mathbf{d}, \mathbf{e} . \mathbf{c}, \mathbf{g}$ Mollisonia symmetrica Walcott, 1912 from the Burgess Shale Lagerstätten, USNM 189155; $\mathbf{c}$ dorsal view; $\mathbf{g}$ detail of $\mathbf{c}$ with tergopleurae outlined showing axial area of overlap (AX) and median ridges (MR) with chevron ridges. Scale bars $5 \mathrm{~mm}$ and $10 \mathrm{~mm}(\mathbf{c}, \mathbf{g})$ 
of cherty mudstones and siltstones assigned to the Drengs Bræ Formation. In southern outcrops, the overlying B $\varnothing \mathrm{g}$ gild Fjord Formation $(240 \mathrm{~m})$ is dominated by quartzitic medium- to thick-bedded fan turbidites which alternate with black mudstones, but the thickness of the southerly derived turbidites decreases dramatically to the north. A prominent composite debris sheet $(20 \mathrm{~m})$ is conspicuous in southern Johannes V. Jensen Land. In general terms, the localities at Sirius Passet and Rypely are similar in preserving starved siliciclastic successions that accumulated offshore from the northern margin of the carbonate-dominated shelf (Higgins et al. 1991a, b).

The age of the lower part of the Vølvedal Group is not constrained by fossils, but it is assumed to be of Cambrian age from regional geological considerations (Higgins et al. 1991a). The middle and upper parts of the group (Bøggild Ford Formation) have yielded Early Ordovician graptolites. Bjerreskov (1989) suggested an age ranging from the Anisograptus Biozone to the Tetragraptus approximatus Biozone of Tremadocian-Floian Age, while Smith and Bjerreskov (1994) cited a Tremadocian age for the uppermost Bøggild Fjord Formation. However, a specimen of Tetragraptus Salter, 1863 from GGU sample 217704 was considered to be of early Arenigian age (Floian) by M. Bjerreskov (written comm. 1980).

\section{Materials and methods}

GGU samples 217703 and 217704 were collected by S.A.S.P. on 21 June 1979 from black shales of the Bøggild Fjord Formation, Vølvedal Group, in Johannes V. Jensen Land, the northern part of Peary Land $\left(82^{\circ} 59^{\prime} 31^{\prime \prime} \mathrm{N}\right.$, $33^{\circ} 46^{\prime} 57^{\prime \prime}$ W; Fig. 1). GGU sample 217704 was collected about $10 \mathrm{~m}$ below sample 217703, the latter yielding the described specimen of Mollisonia? sp.
Macrofossils were whitened with ammonium chloride sublimate prior to digital photography. Shale from the same samples was subjected to acid maceration designed for the recovery of organic-walled microfossils (OWM, including acritarchs and small carbonaceous fossils). Approximately $50 \mathrm{~g}$ of rock from each of the two samples was treated with hydrofluoric (HF) acid (40\% concentration). Following HF treatment, the remaining organic residues were neutralised with water and rinsed over a $40 \mu \mathrm{m}$ mesh sieve. Organicwalled microfossils were hand-picked from suspension (following the technique described in Butterfield and Harvey 2012), mounted onto glass slides and studied under transmitted light.

Abbreviations and repositories. GGU prefix-indicates a sample of Grønlands Geologiske Undersøgelse (Geological Survey of Greenland), now a part of the Geological Survey of Denmark and Greenland (GEUS), Copenhagen, Denmark; MGUH prefix-denotes a specimen deposited in the type collection of the Natural History Museum of Denmark, Copenhagen; USNM prefix - denotes a specimen deposited in the US National Museum of Natural History, Washington D.C.

\section{Associated fossils}

\section{Macrofossils}

In addition to Mollisonia? sp., GGU sample 217703 contains scattered sponge spicules (Fig. 3c), and similar spicules are distributed through most of the Rypely section (J.S.P. unpublished observation 1979). GGU sample 217704 also contains rare three-dimensionally preserved spicules (Fig. 3e), together with poorly preserved hexactin-bearing sponges of uncertain phylogenetic position (J.P. Botting, written comm.
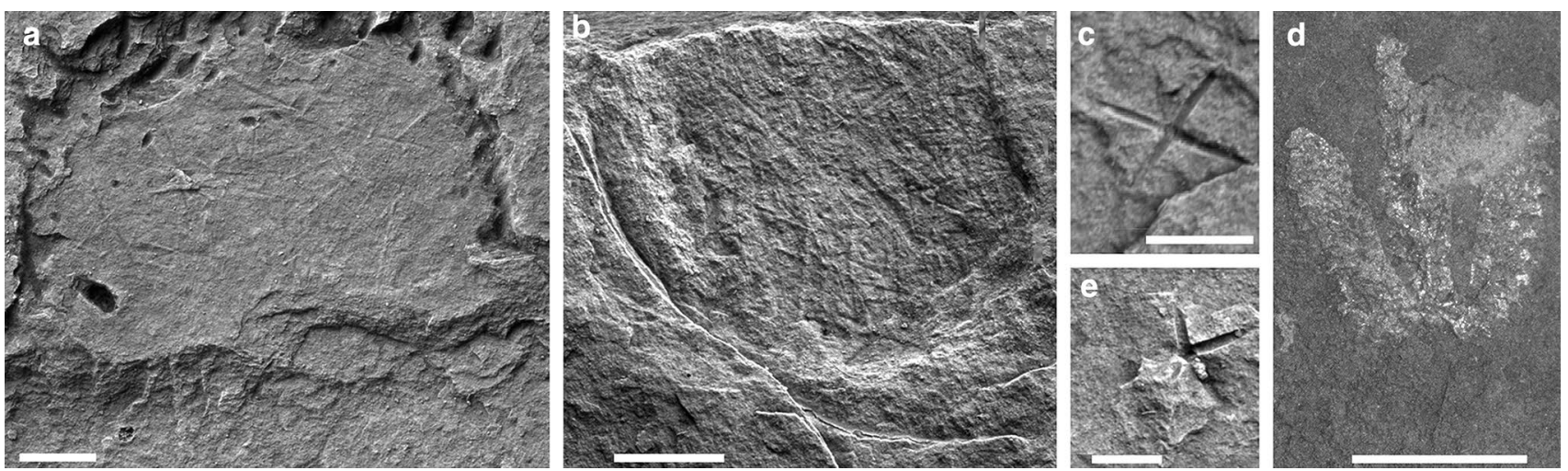

Fig. 3 a-c, e Sponge remains from the Bøggild Formation at Rypely; a MGUH 33389 from GGU sample 217704; b MGUH 33390 from GGU sample 217704; c MGUH 33391 from GGU sample 217703; e MGUH 33392 from GGU sample 217704; d Tetragraptus sp., MGUH 33393 from GGU sample 217704. Scale bars $2 \mathrm{~mm}(\mathbf{a}, \mathbf{b})$, $1 \mathrm{~mm}(\mathbf{c}, \mathbf{e})$ or $5 \mathrm{~mm}(\mathbf{d})$ 
2019; Fig. 3a, b). Both samples show numerous indistinct traces of largely resorbed organic material amongst which sheaves of fine needle-like sponge spicules are abundant. The graptolite Tetragraptus sp. (Fig. 3d) was identified from GGU sample 217704 by Merete Bjerreskov (written comm. 1980), considered indicative of an early Arenigian age (Early Ordovician, Floian).

\section{Organic-walled microfossils}

Ordovician assemblages of organic-walled microfossils often consist of highly ornate and morphologically varied acritarchs. By comparison, the collections of OWM from Rypely show a somewhat depauperate ecosystem that could indicate distance to the palaeoshore. In terms of Proterozoic microfossil distributions, the fauna presented here would be regarded as distal shelf (Butterfield and Chandler 1992), which accords well with the depositional setting of the Vølvedal Group proposed by Higgins et al. (1991a, b).

The organic-walled microfossils are poorly preserved, and the organic matter is dark brown in colour on account of thermal alteration of the samples (Fig. 4). Simple, spheroidal acritarchs ( $80-150 \mu \mathrm{m}$ in diameter) referred to as Leiosphaeridia sp. are common in the samples. It is notable that several specimens display concentric thickenings around the vesicle perimeter, possibly a result of compression in the shale (Grey and Willman 2009). Many specimens also display bulb- or neck-like protrusions of various kinds (Fig. 4a). A few specimens (Fig. 4h) show a vesicle architecture consisting of fused bands similar to a problematic OWM called Moyeria Thusu, 1973. Moyeria has euglenid-like features and is described from freshwater systems from the Ordovician-Silurian of several palaeocontinents, with occurrences including Pennsylvania, USA, and Gotland, Sweden (Gray and Boucot 1989; Martin 1989; Martín-Closas 2003). A possible metazoan fragment, preserved as a flattened spine that seems to taper towards a now missing tip, was also recovered (Fig. 4e). Similar spines from Cambrian assemblages of small carbonaceous fossils were assigned to the protoconodont Protohertzina Missarzhevsky, 1973 by Slater et al. (2018) and Slater and Willman (2019), but the Rypely specimen is too poorly preserved for identification.

\section{Systematic palaeontology}

Euarthropoda sensu Walossek, 1999

Order Mollisoniida Simonetta and Della Cave, 1975

Family Mollisoniidae Simonetta and Della Cave, 1975

Genus Mollisonia Walcott, 1912
Type species. Mollisonia symmetrica Walcott, 1912 from the Burgess Shale of British Columbia, Canada (Walcott 1912: p. 196, pl. 24, fig. 3); middle Cambrian (Miaolingian Series; Drumian Stage).

Discussion. Conway Morris and Robison (1988: p. 28) corrected the consistent misspelling Mollinsonia by Simonetta and Della Cave (1975: p. 5), which was perpetuated at family and ordinal level by Simonetta and Della Cave (1975: p. 32) and repeated by Simonetta (2004: fig. 13).

Mollisonia is a relatively rare arthropod originally described from the middle Cambrian (Miaolingian) Burgess Shale Lagerstätte of British Columbia (Walcott 1912). Specimens of Mollisonia from the Burgess Shale are well illustrated on The Burgess Shale website of the Royal Ontario Museum, while an exceptional specimen was illustrated from the Marble Canyon locality of the Burgess Shale by Caron et al. (2014).

Mollisonia is known from strata of similar Miaolingian age in Utah (Robison 1991; Briggs et al. 2008) and from the Kaili Biota (Miaolingian) of South China (Zhang et al. 2002; Zhou et al. 2002). It was also illustrated by Zhu et al. (2016) from the Guole Biota (Furongian) of South China. Van Roy (2011) and Van Roy et al. (2015) listed Mollisonia from lowest Ordovician (Tremadocian) strata of the Fezouata Lagerstätte in Morocco.

\section{Mollisonia? sp.}

Figures 2a, b, d-f, 5a, b, e

Description. The single incomplete specimen (MGUH 33388) has a length of $52 \mathrm{~mm}$ and is preserved as part (Fig. 2a) and counterpart (Fig. 2d) in black shale. The anterior of the specimen is missing; the transverse break appears to have taken place within the thorax and corresponds to the present edge of the slab. The part lies at a slightly lower level than the lamination currently forming the surface of the slab such that sediment overlies the fossil impression along its margins (Fig. 2a, b). In consequence, the counterpart is raised slightly above the general slab surface (Fig. 2d). Although compressed, both the part and counterpart retain slight relief, with the part being slightly convex (Fig. 2a).

The specimen tapers slightly towards the posterior during the anterior four-fifths of its preserved length before terminating in a triangular tail shield (Figs. 2a, d, 5a). The increasing obliquity towards the posterior of the constituent tergopleurae suggests that the specimen has been flattened slightly obliquely during diagenesis, with the tail shield turned down into the sediment.

Eight tergopleurae are preserved in the thorax, although the first of these may represent the posterior margin of the head shield. The overlapping of the preceding tergopleura by the convex anterior of the following tergopleura (Fig. 2a, 


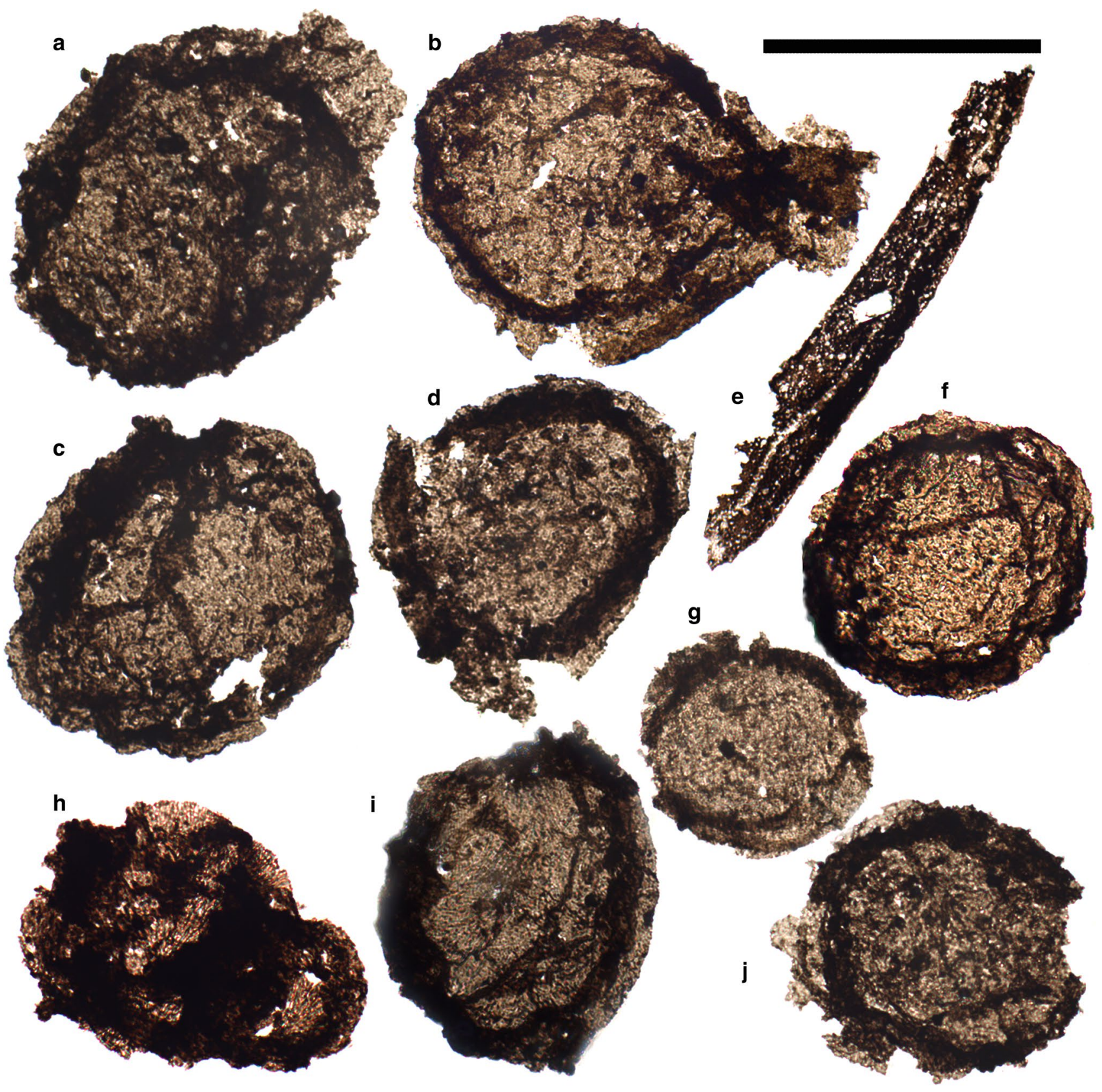

Fig. 4 Organic-walled microfossils from the Bøggild Fjord Formation at Rypely. a, b Leiosphaeridia sp., GGU samples 217703-03013 (a) and 217703-07-001 (b), showing neck-like protrusion at one end; c Leiosphaeridia sp., GGU sample 217703-03-006, showing a trilete wall appearance; d Leiosphaeridia sp., GGU sample 21770301, showing thick, concentric compression folds on the perimeter;

e) indicates that the specimen is essentially a mould of the interior surface of the tagma and that part and counterpart represent the same surface.

Both the anterior and posterior edges of the thoracic tergopleurae are reinforced by narrow thickened margins, the latter most clearly visible in the anterior part of the thorax where the tergopleurae have separated slightly (Fig. 2a, PD). e possible metazoan spine, GGU sample 217703-05-009; f, g Leiosphaeridia sp., GGU samples 217703-05-006 (f) and 217703-02-008 (g); h, i Moyeria? sp., GGU samples 217704-05-002 (h) and 21770302-005 (i), showing wall structure consisting of fused lamellar bands; j Leiosphaeridia sp., GGU sample 217703-02, showing several bulbous protrusions. Scale bar $100 \mu \mathrm{m}$

In contrast, the thickened anterior margin is most readily discerned in the posterior thorax (Fig. 2e, arrows 1-5). As preserved, the posterior margin of the tergopleurae is shallowly convex in dorsal view towards the posterior (Fig. 2a), whereas the anterior margin is strongly convex towards the front (Fig. 2e). In detail, the overall uniform convexity of the anterior margin is interrupted by shallow concavities 
a

tergopleurae

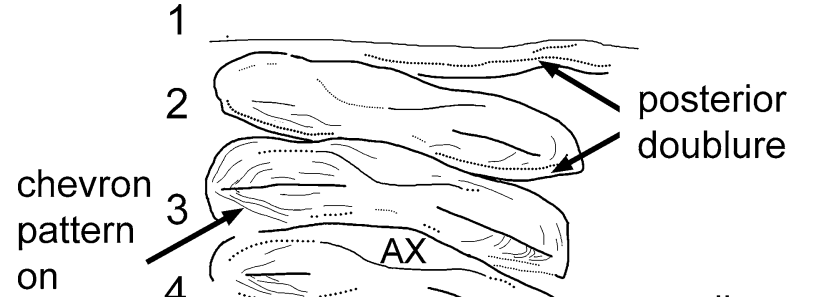

petaloids

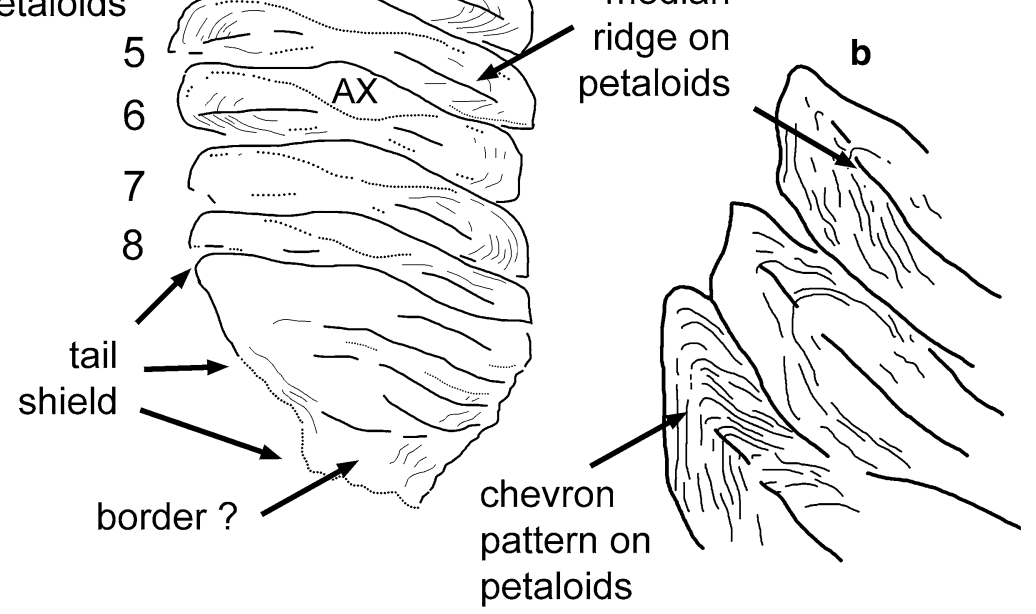

C

tergopleurae
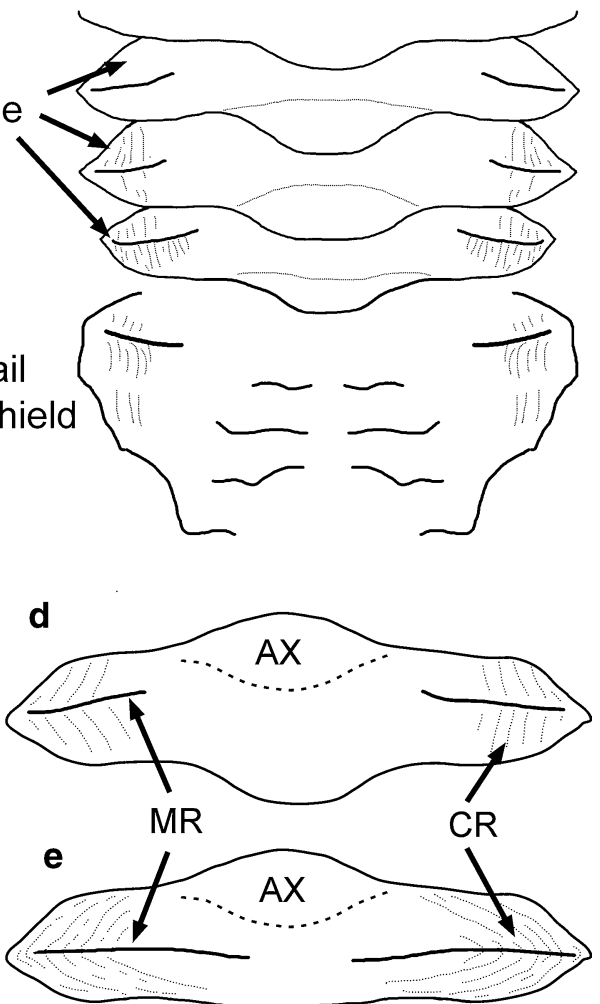

Fig. 5 a, b, e Interpretive sketches of Mollisonia? sp. from the Bøggild Formation at Rypely, based on Fig. 2a, f; a dorsal view of specimen; $\mathbf{b}$ detail of petaloids, anterior is down; $\mathbf{e}$ tergopleura (schematic). c, $\mathbf{g}$ Interpretive sketches of Mollisonia symmetrica from the

located one on each side of the axial culmination of the curve (Fig. 2e, arrows 2 and 3). The slightly sinuous form of the anterior margin may suggest a weak trilobation of the dorsal surface, but it may also reflect the point of overlap between consecutive tergopleurae. The axial extension of the anterior margin (AX in Fig. 2e) lies beneath the posterior margin of the preceding tergopleura and is therefore functionally equivalent to the articulating half ring of trilobites. With increase in curvature of the anterior margin, each tergopleura terminates laterally in a sharp, near perpendicular angular relationship with the posterior margin (Fig. 2f), sometimes culminating in a short spine.

Each tergopleura, in dorsal view, appears to encompass three elliptical areas (Fig. 2a, b, d, e) although the axial ellipse (AX in Figs. 2b, e, 5a) results from the interaction of the anterior margins of the inflated lateral ellipses (herein referred to as petaloids) with the anterior margin of the tergopleura. Each petaloid narrows towards the axis, although the nature of their contact at the axis is obscure. The petaloids are raised, shallowly convex, on the internal mould (Fig. 2a, b) and grade over a short distance into the flattened margins of the tergopleura (Fig. 2b, f). A narrow median ridge can be traced along each petaloid from near the thorax axis towards the tergopleural lateral extremity (MR
Burgess Shale Lagerstätten of Canada, based on Fig. 2c, g; c posterior part of thorax and tail shield; left side is mirror image of right side; g tergopleura (schematic). $A X$ axial area of tergopleura, $C R$ chevron ridges, $M R$ medial ridge on petaloids

in Figs. 2e, f, $5 \mathrm{a}, \mathrm{b}$ ). It is crossed by a chevron pattern of $\mathrm{V}$-shaped ridges with their apices lying along the ridge and directed away from the thoracic axis (CR in Figs. 2b, f, 5b). The individual ridges are steepened on their abaxial margin and locally may appear to represent shallowly inclined lamellae, stacked such that the youngest lamellae are those nearest the thorax axis (CR in Fig. 2b, f).

The poorly preserved tail shield (Figs. 2a, 5a) is distinguished largely on account of the change in preservation of the tergopleurae, although this may result in part from the oblique compression. Tergopleural boundaries are raised as acute ridges, in contrast to the depressed tergopleural margins elsewhere on the internal mould (Fig. 2a, b), and are formed into a fan on account of pre-diagenetic curvature of the trunk (Fig. 2a, d). Six pleurae seem to be present, seemingly followed by a flat border (B in Fig. 2e).

Discussion. Mollisonia? sp. from Rypely can be compared to Mollisonia symmetrica from the Burgess Shale Lagerstätte (Figs. 2c, g, 5c, d) in terms of the morphology of its tergopleurae and the sculpture of the petaloids. The compared specimen of Mollisonia symmetrica Walcott, 1912 (Fig. 2c, g) was illustrated in colour by Jean-Bernard Caron on The Burgess Shale website of the Royal Ontario Museum. It is 
emphasised, however, that the incomplete preservation of the single specimen from Rypely permits only a tentative assignment to Mollisonia. The thorax of Mollisonia? differs from that of Mollisonia symmetrica in possessing eight rather than seven preserved tergopleurae, although the exact number of tergopleurae is not known.

The presence of three elliptical areas in each tergopleura of Mollisonia? sp., with an inflated (on the internal mould) and ornamented petaloid located on each side of an axial ellipse (Fig. 2a, b, d, e), is reminiscent of tergopleurae of Mollisonia symmetrica (Fig. 2c, g). However, delimitation of the axial ellipse in Mollisonia symmetrica (AX in Fig. 2g) is emphasised by the strongly convex posterior extension of the axial area of the overlapping tergopleura (Fig. 5d), contrasting with the shallowly convex posterior margin in Mollisonia? sp. (Fig. 5e). The substantial axial overlap of the underlying anterior margin of tergopleurae by the overlying posterior margin of the preceding tergopleurae in Mollisonia symmetrica implies a greater capacity for tight enrolment relative to Mollisonia? sp.

At first glance, the leaf-like form of the paired petaloids suggests that they may reflect internal anatomy, but this is rejected. Several arthropods and lobopodians from Sirius Passet and other Lagerstätten preserve laterally disposed digestive glands (Vannier et al. 2014), but these are relatively small structures located close to the gut, unlike the elongate petaloids which occupy most of the lateral areas of each tergopleura. Furthermore, the concentric chevron pattern seen in the petaloids of Mollisonia? sp. is quite unlike the radial anastomosing structure often seen in digestive glands (Budd 1997; Vannier et al. 2014). The chevron pattern on the petaloids may locally give the impression of stacked lamellae (Fig. 2f). While such lamellae have been described in the exopod of Naraoia compacta Walcott, 1912 from the Burgess Shale Lagerstätte by Haug and Haug (2016), there is little morphological similarity between the two structures or other indication that the petaloids reflect exopods or other parts of limbs.

Stein et al. (2013) described a wrinkled inner lamella of the cuticle in the Sirius Passet arthropod Arthroaspis bergstroemi Stein, Budd, Peel and Harper, 2013, but the wrinkles are perpendicular to the tergopleural margins and do not form chevrons. An inner lamella is present in some agnostoids (Müller and Walossek 1987), and is also characteristic of several groups of bivalved arthropods. In these, the wrinkles usually parallel the doublure margin (Müller 1979; Müller and Walossek 1987; Maas et al. 2003; Liu and Dong 2010; Page et al. 2010; Stein et al. 2010), unlike the chevron pattern in Mollisonia? sp.

The petaloid pattern of median ridge and chevrons is likely derived from the outer cuticle. Tergopleurae in trilobites often display pleural furrows rather than ridges, but median tergopleural ridges are present in Mollisonia symmetrica (Fig. 2c, g) and other Cambrian arthropods (Hou et al. 2017: figs. 20.6a, 20.9b, 20.39d). A similar combination of chevron ridges and median ridge pattern is seen in the illustrated specimen of Mollisonia symmetrica from the Burgess Shale Lagerstätte (Figs. 2c, g, 5c, d). In the latter, however, the fine ridges of the chevrons are almost perpendicular to the median ridge, much less acutely V-shaped than in Mollisonia? sp. Similar terrace ridges or lirae occur commonly on the dorsal surface of trilobites (Miller 1975; Brown 2005; Seilacher and Gishlick 2015) or, less commonly, on skeletal elements of other arthropods (Savazzi 1981, 1985, 2003). Interpretations of their purpose are varied, but a sensory function or mechanical stabilising, frictional interaction with the sediment is usually invoked (Miller 1975; Brown 2005). The cuesta-like cross section typical of terrace ridges is seen in the chevron ridges of several petaloids (Fig. 2f), with the steepened scarp surface facing the lateral margin of the tergopleura. The presence of the terrace lines suggests that Mollisonia? sp. spent resting periods just below a thin sediment layer, possibly emerging during feeding.

Terrace ridges in trilobites and other arthropods obviously occur on the outer surface of the cuticle. Thus, the anomalous preservation of chevron ridges of Mollisonia? sp. on surfaces interpreted as representing moulds of the interior of tergopleurae indicates superimposition during compaction of the sculpture pattern from the cuticle exterior on the mould of the interior surface.

Acknowledgements Open access funding provided by Uppsala University. Jean-Bernard Caron (Royal Ontario Museum) kindly provided the coloured photograph of Mollisonia symmetrica (USNM 189155) from which Fig. 2c, g was prepared. Thanks are due to J.P. Botting (National Museum of Wales) for comments concerning the sponge remains, to Elise Wallet (Uppsala University) for photography of OWM (Fig. 4), and to Arden Roy Bashforth (Natural History Museum of Denmark), John Boserup (GEUS) and Jon Ineson (GEUS) for help with regard to collections of their respective institutions. J.O.R. Ebbestad (Museum of Evolution, Uppsala), Xingliang Zhang (Northwest University, Xi' an) and the Editor-in-Chief Mike Reich (SNSB-BSPG Munich) are thanked for comments on the submitted manuscript.

Open Access This article is distributed under the terms of the Creative Commons Attribution 4.0 International License (http://creativeco mmons.org/licenses/by/4.0/), which permits unrestricted use, distribution, and reproduction in any medium, provided you give appropriate credit to the original author(s) and the source, provide a link to the Creative Commons license, and indicate if changes were made.

\section{References}

Bjerreskov, M. 1989. Ordovician graptolite biostratigraphy in North Greenland. Rapport Grønlands Geologiske Undersøgelse 144: $17-33$.

Botting, J.P., L.A. Muir, N. Jordan, and C. Upton. 2015. An Ordovician variation on Burgess Shale-type biotas. Science Reports 5: 9947. https://doi.org/10.1038/srep09947. 
Botting, J.P., L.A. Muir, M. Sutton, and T. Barnie. 2011. Welsh gold: A new exceptionally preserved pyritized Ordovician biota. Geology 39: 879-882.

Briggs, D.E.G., D.H. Erwin, and F.J. Collier. 1994. The fossils of the Burgess Shale, 1-238. Washington D.C.: Smithsonian Institution Press.

Briggs, D.E.G., B. Lieberman, J.F. Hendricks, S.L. Halgedahl, and R.D. Jarrard. 2008. Middle Cambrian arthropods from Utah. Journal of Paleontology 82: 238-254.

Brown, A.M. 2005. Terrace ridges in trilobites. 1-299. Edinburgh: Unpublished Ph.D thesis, University of Edinburgh.

Budd, G.E. 1997. Stem group arthropods from the Lower Cambrian Sirius Passet fauna of North Greenland. In Arthropod relationships, eds. R.A. Fortey and A.H. Thomas, 127-140. London: Chapman and Hall.

Budd, G.E. 1999a. The morphology and phylogenetic significance of Kerygmachela kierkegaardi Budd (Buen Formation, Lower Cambrian, N Greenland). Transactions of the Royal Society of Edinburgh, Earth Sciences 89: 249-290.

Budd, G.E. 1999b. A nektaspid arthropod from the early Cambrian Sirius Passet fauna, with a description of retrodeformation, based on functional morphology. Palaeontology 42: 99-122.

Budd, G.E. 2011. Campanamuta mantonae gen. et sp. nov., an exceptionally preserved arthropod from the Sirius Passet Fauna (Buen Formation, lower Cambrian, North Greenland). Journal of Systematic Palaeontology 9: 217-260.

Budd, G.E., and J.S. Peel. 1998. A new xenusiid lobopod from the Early Cambrian Sirius Passet fauna of North Greenland. Palaeontology 41: 1201-1213.

Butterfield, N.J., and F.W. Chandler. 1992. Palaeoenvironmental distribution of Proterozoic microfossils, with an example from the Agu Bay Formation, Baffin Island. Palaeontology 35: 943-957.

Butterfield, N.J., and T.H.P. Harvey. 2012. Small carbonaceous fossils (SCFs): a new measure of early Paleozoic paleobiology. Geology 40: 71-74.

Caron, J.-B., R.R. Gaines, C. Aria, M.G. Mángano, and M. Streng. 2014. A new phyllopod bed-like assemblage from the Burgess Shale of the Canadian Rockies. Nature Communications. https ://doi.org/10.1038/ncomms4210.

Conway Morris, S., and R.A. Robison. 1988. More soft-bodied animals and algae from the Middle Cambrian of Utah and British Columbia. University of Kansas Paleontological Contributions 122: $1-48$.

Conway Morris, S., J.S. Peel, A.K. Higgins, N.J. Soper, and N. Davis. 1987. A Burgess Shale-like fauna from the Lower Cambrian of Greenland. Nature 326: 181-183.

Friderichsen, J.D., A.K. Higgins, J.M. Hurst, S.A.S. Pedersen, N.J. Soper, and F. Surlyk. 1982. Lithostratigraphic framework of the Upper Proterozoic and Lower Palaeozoic deep water clastic deposits of North Greenland. Rapport Grønlands Geologiske Undersøgelse 107: 1-19.

Fu, D., G. Tong, T. Dai, W. Liu, Y. Yang, Y. Zhang, L. Cui, L. Li, H. Yun, Y. Wu, A. Sun, C. Liu, W. Pei, R.R. Gaines, and X. Zhang. 2019. The Qingjiang biota—a Burgess Shale-type fossil Lagerstätte from the early Cambrian of South China. Science 363: 1338-1342.

Gabbott, S.E., C. Browning, J.N. Theron, and R.J. Whittle. 2017. The late Ordovician Soom Shale Lagerstätte: an extraordinary postglacial fossil and sedimentary record. Journal of the Geological Society 174: 1-9.

Gray, J., and A.J. Boucot. 1989. Is Moyeria a euglenoid? Lethaia 22: 447-456.

Grey, K., and S. Willman. 2009. Taphonomy of Ediacaran acritarchs from Australia: Significance for taxonomy and biostratigraphy. Palaios 24: 239-256.
Grønnow, B., and J.F. Jensen. 2009. The northernmost ruins of the globe. Eigil Knuth's Archaeological Investigations in Peary Land and adjacent areas of high Arctic Greenland. Monographs on Greenland, Man and Society 29: 1-403. (=Meddelelser om Gronland 329).

Haug, C., and J.T. Haug. 2016. New insights into the appendage morphology of the Cambrian trilobite-like arthropod Naraoia compacta. Bulletin of Geosciences 91: 221-227.

Higgins, A.K. 1986. Geological map of Greenland, 1:100000, Harder Fjord. Copenhagen: Grønlands Geologiske Undersøgelse.

Higgins, A.K., J.R. Ineson, J.S. Peel, F. Surlyk, and M. Sønderholm. 1991a. Lower Palaeozoic Franklinian Basin of North Greenland. Bulletin Grønlands Geologiske Undersøgelse 160: 71-139.

Higgins, A.K., J.R. Ineson, J.S. Peel, F. Surlyk, and M. Sønderholm. 1991b. Cambrian to Silurian basin development and sedimentation, North Greenland. In Geology of the Innuitian Orogen and Arctic Platform of Canada and Greenland, Geology of Canada, vol. 3, ed. H.P. Trettin, 109-161. Ottawa: Geological Survey of Canada. (=Decade of North American Geology, The geology of North America Volume E, Boulder, Colo.: Geological Society of America).

Holmes, J.D., D.C. García-Bellido, and M.S.Y. Lee. 2018. Comparisons between Cambrian Lagerstätten assemblages using multivariate, parsimony and Bayesian methods. Gondwana Research 55: $30-41$.

Hou, X., D.J. Siveter, R.J. Siveter, R.J. Aldridge, P. Cong, S.E. Gabbott, X. Ma, M.A. Purnell, and M. Williams. 2017. The Cambrian fossils of Chengjiang, China. The flowering of early animal life, 2nd ed. Chichester: Wiley Blackwell.

Ineson, J.R., and J.S. Peel. 1997. Cambrian shelf stratigraphy of North Greenland. Geology of Greenland Survey Bulletin 173: 1-120.

Ineson, J.R., and J.S. Peel. 2011. Geological and depositional setting of the Sirius Passet Lagerstätte (early Cambrian), North Greenland. Canadian Journal of Earth Sciences 48: 1259-1281.

Lefebvre, B., K. El Hariri, R. Lerosey-Aubril, T. Servais, and P. Van Roy. 2016. The Fezouata Biota: an exceptional window on the Cambro-Ordovician faunal transition. Palaeogeography, Palaeoclimatology, Palaeoecology 460: 1-178.

Liu, Z., and X. Dong. 2010. The development trend of labrum and median eyes of Orsten-type preserved Phosphatocopina (Crustacea). Science China Earth Sciences 53: 18-26.

Maas, A., D. Waloszek, and K.J. Müller. 2003. Morphology, ontogeny and phylogeny of the Phosphatocopina (Crustacea) from the Upper Cambrian "Orsten" of Sweden. Fossils and Strata 49: $1-238$.

Martin, É.L.O., B. Pittet, J.C. Gutiérrez-Marco, K.H. El Hariri, R. Lerosey-Aubril, M. Masrour, T. Servais, T.R.A. Vandenbroucke, J. Vannier, P. Van Roy, R. Vaucher, and B. Lefebvre. 2016. Age and environmental setting of the Lower Ordovician Fezouata Biota (Zagora, Morocco). Gondwana Research 34: 274-283.

Martin, F. 1989. Chapter 20: Acritarchs. In A global standard for the Silurian System, eds. C.H. Holland and M.G. Bassett, 207-219. Cardiff: Natural Museum of Wales.

Martín-Closas, C. 2003. The fossil record and evolution of freshwater plants: A review. Geologica Acta 1: 315-338.

Miller, J. 1975. Structure and function of trilobite terrace lines. Fossils and Strata 4: 155-178.

Missarzhevsky, V.V. 1973. Conodontomorph organisms from the Precambrian-Cambrian boundary beds of the Siberian Platform and Kazakhstan [in Russian]. In Problemy paleontologii $i$ biostratigrafii nižnego kembriâ Sibiri i Dal'nego Vostoka, ed. I.T. Zhuravleva, 53-58. Novosibirsk: Nauka.

Müller, K.J. 1979. Phosphatocopine ostracodes with preserved appendages from the Upper Cambrian of Sweden. Lethaia 12: 1-27. 
Müller, K.J., and D. Walossek. 1987. Morphology, ontogeny, and life habit of Agnostus pisiformis from the Upper Cambrian of Sweden. Fossils and Strata 19: 1-124.

Page, A., P.R. Wilby, M. Williams, J. Vannier, J.R. Davies, R.A. Waters, and J.A. Zalsiewicz. 2010. Soft-part preservation in a bivalved arthropod from the Late Ordovician of Wales. Geological Magazine 147: 242-252.

Pedersen, S.A.S., and N. Henriksen. 1986. Geological map of Greenland, 1:100000, Nordkronen. Copenhagen: Grønlands Geologiske Undersøgelse.

Peel, J.S. 2017. Molaria (Euarthropoda) from the Sirius Passet Lagerstätte (Cambrian Series 2, Stage 3) of North Greenland. Bulletin of Geosciences 92: 133-142.

Peel, J.S., and J.R. Ineson. 2011a. The Sirius Passet Lagerstätte (early Cambrian) of North Greenland. Palaeontographica Canadiana 31: 109-118.

Peel, J.S., and J.R. Ineson. 2011b. The extent of the Sirius Passet Lagerstätte (early Cambrian) of North Greenland. Bulletin of Geoscience 86: 535-543.

Peel, J.S., and M. Stein. 2009. A new arthropod from the lower Cambrian Sirius Passet Fossil-Lagerstätte of North Greenland. Bulletin of Geosciences 84: 625-630.

Peel, J.S., and S. Willman. 2018. The Buen formation (Cambrian Series 2) biota of North Greenland. Papers in Palaeontology 4: 381-432.

Robison, R.A. 1991. Middle Cambrian biotic diversity: Examples from four Utah lagerstätten. In The early evolution of metazoa and the significance of problematic taxa, eds. A. Simonetta and S. Conway Morris, 77-98. Cambridge: Cambridge University Press.

Royal Ontario Museum. The Burgess Shale (https://burgess-shale.rom. on.ca/en/). Specimens of Mollisonia symmetrica are illustrated on https://burgess-shale.rom.on.ca/en/fossil-gallery/view-speci es.php?id=84\&ref $=\mathrm{i} \&$.

Salter, J.W. 1863. Note on the Skiddaw slate fossils. Quarterly Journal of the Geological Society of London 19: 135-140.

Savazzi, E. 1981. Functional morphology of the cuticular terraces in Ranina (Lophoranina) (brachyuran decapods; Eocene of NE Italy). Neues Jahrbuch für Geologie und Paläontologie, Abhandlungen 162: 231-243.

Savazzi, E. 1985. Functional morphology of the cuticular terraces in burrowing terrestrial brachyuran decapods. Lethaia 18: 147-154.

Savazzi, E. 2003. Function of terrace patterns in Stomatopoda (Crustacea) and Mantodea (Insecta). In Morphogenesis and pattern formation in biological systems: Experiments and models, eds. T. Sekimura, S. Noji, N. Ueno, and P.K. Maini, 379-389. Berlin: Springer.

Seilacher, A. 1970. Begriff und Bedeutung der Fossil-Lagerstätten. Neues Jahrbuch für Geologie und Paläontologie, Monatshefte 1970: 34-39.

Seilacher, A., and A.D. Gishlick. 2015. Morphodynamics. Boca Raton: CRC Press

Simonetta, A.M. 2004. Are the traditional classes of arthropods natural ones? Recent advances in palaeontology and some considerations on morphology. Italian Journal of Zoology 71: 247-264.

Simonetta, A.M., and L. Delle Cave. 1975. The Cambrian non trilobite arthropods from the Burgess shale of British Columbia. A study of their comparative morphology, taxonomy, and evolutionary significance. Palaeontographia Italica 69: 1-37. (= Palaeontographia Italica n.s. 39)

Slater, B.J., T.H.P. Harvey, and N.J. Butterfield. 2018. Small carbonaceous fossils (SCFs) from the Terreneuvian (lower Cambrian) of Baltica. Palaeontology 61: 417-439.

Slater, B.J., and S. Willman. 2019. Early Cambrian small carbonaceous fossils (SCFs) from an impact crater in western Finland. Lethaia. https://doi.org/10.1111/let.12331.
Slater, B.J., S. Willman, G.E. Budd, and J.S. Peel. 2017. Widespread preservation of small carbonaceous fossils (SCFs) in the early Cambrian of North Greenland. Geology 46: 107-110.

Smith, M.P., and M. Bjerreskov. 1994. The Ordovician System in Greenland. International Union of Geological Sciences 29: 1-46.

Smith, M.P., and J.A. Rasmussen. 2008. Cambrian-Silurian development of the Laurentian margin of the Iapetus Ocean in Greenland and related areas. In The Greenland Caledonides: Evolution of the Northeast Margin of Laurentia, eds. A.K. Higgins, J.A. Gilotti, and M.P. Smith. Geological Society of America, Memoir 202: 137-167.

Stein, M. 2010. A new Cambrian arthropod from Greenland. Zoological Journal of the Linnean Society 158: 477-500.

Stein, M., J.S. Peel, D.J. Siveter, and M. Williams. 2010. Isoxys (Arthropoda) with preserved soft anatomy from the Sirius Passet Lagerstätte, lower Cambrian of North Greenland. Lethaia 43: 258-265.

Stein, M., G.E. Budd, J.S. Peel, and D.A.T. Harper. 2013. Arthroaspis n. gen., a common element of the Sirius Passet Lagerstätte (Cambrian, North Greenland), sheds light on trilobite ancestry. BMC Evolutionary Biology 13(99): 1-34. https://doi. org/10.1186/1471-2148-13-99.

Stijl, F.W. van der, and G.Z. Mosher. 1998. The Citronen Fjord massive sulphide deposit, Peary Land, North Greenland: discovery, stratigraphy, mineralization and structural setting. Geology of Greenland Survey Bulletin 179: 1-44.

Thusu, B. 1973. Acritarches provenant de l'Ilion Shale (Wenlockien) Utica, New York. Révue de Micropaléontotologie 16: 137-146.

Trettin, H.P. 1989. The Arctic Islands. In The geology of North America: an overview, the geology of North America A, ed. A.W. Bailly and A.P. Palmer, 349-370. Boulder: Geological Society of America.

Trettin, H.P. (ed.). 1991. Geology of the Innuitian Orogen and Arctic Platform of Canada and Greenland. Geology of Canada, vol. 3, 1-569. Ottawa: Geological Survey of Canada. (=The geology of North America E, Boulder, Colo.: Geological Society of America).

Vannier, J., J. Liu, R. Lerosey-Aubril, J. Vinther, and A.C. Daley. 2014. Sophisticated digestive systems in early arthropods. Nature Communications. https://doi.org/10.1038/ncomms4641.

Van Roy, P. 2011. New non-trilobite arthropods from the early Ordovician Fezouata Biota of Morocco. Geological Society of America annual meeting and exposition, abstracts. https://gsa.confex.com/ gsa/2011AM/webprogram/Paper195912.html.

Van Roy, P., D.E.G. Briggs, and R.R. Gaines. 2015. The Fezouata fossils of Morocco; an extraordinary record of marine life in the Early Ordovician. Journal of the Geological Society 172: 541-549.

Van Roy, P., P.J. Orr, J.P. Botting, L.A. Muir, J. Vinther, B. Lefebvre, K. el Hariri, and D.E.G. Briggs. 2010. Ordovician faunas of Burgess Shale type. Nature 465: 215-218.

Walcott, C.D. 1912. Cambrian geology and paleontology II. No. 6. Middle Cambrian Branchiopoda, Malacostraca, Trilobita, and Merostomata. Smithsonian Miscellaneous Collections 57: 145-229.

Walossek, D. 1999. On the Cambrian diversity of Crustacea. In Crustaceans and the biodiversity crisis, Amsterdam, The Netherlands, July 20-24, 1998, vol. 1, eds. F.R. Schram and J.C. von Vaupel Klein, 3-27. Leiden: Brill Academic Publishers.

Young, G.A., D.M. Rudkin, E.P. Dobrzanski, S.P. Robson, and G.S Nowlan. 2007. Exceptionally preserved Late Ordovician biotas from Manitoba, Canada. Geology 35: 883-886.

Zhang, X., Y. Zhao, R. Yang, and D. Shu. 2002. The Burgess Shale arthropod Mollisonia (M. sinica new species): new occurrence from the Middle Cambrian Kaili Fauna of Southwest China. Journal of Paleontology 76: 1106-1108. 
Zhao, Y., J. Yuan, M. Zhu, R. Yang, Q. Guo, J. Peng, and X. Yang. 2002. Progress and significance in research on the early Middle Cambrian Kaili Biota, Guizhou Province, China. Progress in Natural Science 12: 649-654.
Zhu, X., S. Peng, S. Zamora, B. Lefebvre, and G. Chen. 2016. Furongian (upper Cambrian) Guole Konservat-Lagerstätte from South China. Acta Geologica Sinica 90: 30-37. 